\title{
Targeted chemotherapy for triple-negative breast cancers via LHRH receptor
}

\author{
CRISPIN FÖST $^{1}$, FRANCESCA DUWE ${ }^{1}$, MARTIN HELLRIEGEL ${ }^{1}$, \\ STEFAN SCHWEYER ${ }^{2}$, GÜNTER EMONS ${ }^{1}$ and CARSTEN GRÜNDKER ${ }^{1}$
}

\begin{abstract}
Departments of ${ }^{1}$ Gynecology and Obstetrics, and ${ }^{2}$ Pathology, Georg-August-University, Göttingen, Germany
\end{abstract}
Received December 23, 2010; Accepted January 28, 2011

DOI: $10.3892 / o r .2011 .1188$

\begin{abstract}
Triple-negative breast cancer does not express estrogen and progesterone receptors and there is no overexpression/amplification of the HER2-neu gene. Therefore, this subtype of breast cancer lacks the benefits of specific therapies which target these receptors. About $60 \%$ of all human breast cancers express receptors for luteinizing hormone releasing hormone (LHRH, GnRH), which might be used as a target. The LHRH receptor can be used for targeted chemotherapy with cytotoxic luteinizing hormone releasing hormone agonists such as AEZS-108 (AN-152), in which doxorubicin is linked to [D-Lys ${ }^{6}$ ]LHRH. In the present study we have analyzed by in vitro and in vivo experiments whether the cytotoxic LHRH agonist AEZS-108 (AN-152) induces apoptosis in triple-negative human breast cancer cells that express LHRH receptors. LHRH receptor expression in tumor biopsy specimens of triple-negative breast cancers was tested using immunohistochemistry. Cell proliferation was analyzed using alamar blue proliferation assay. Induction of apoptosis was quantified by measurement of loss of mitochondrial membrane potential. In vivo experiments were performed using nude mice bearing xenografted human breast tumors. Thirty-one of 42 triple-negative breast cancers $(73.8 \%)$ expressed LHRH receptors. We could show that treatment of triple-negative but LHRH-positive MDA-MB-231, HCC1806 and HCC1937 human breast cancer cells with AEZS-108 (AN-152) resulted in apoptotic cell death in vitro via activation of caspase-3. The antitumor effects were confirmed in nude mice. AEZS-108 (AN-152) inhibited the growth of xenotransplants of triple-negative human breast cancers in nude mice completely, without any apparent side effects. The cytotoxic LHRH agonist AEZS-108 (AN-152) seems to be a suitable drug for an efficacious therapy for triple-negative breast cancers with little toxicity.
\end{abstract}

Correspondence to: Dr Carsten Gründker, Department of Gynecology and Obstetrics, Robert-Koch-Street 40, 37075 Göttingen, Germany

E-mail: grundker@med.uni-goettingen.de

Key words: luteinizing hormone releasing hormone receptor, targeted therapy, AN-152, triple-negative breast cancer

\section{Introduction}

Breast cancer is the most frequent malignant disease in women, with more than 1,000,000 new cases and 370,000 deaths yearly worldwide (1). About $75-80 \%$ of breast cancers are hormone receptor-positive and express estrogen and/ or progesterone receptors (2,3). Approximately $15-20 \%$ of breast cancers overexpress the HER2-neu gene, with around half of these co-expressing steroid hormone receptors. For patients with hormone-receptor-positive or HER2-neu-positive tumors effective targeted therapies have been developed. About 10-15\% of breast cancers do not express either estrogen or progesterone receptors, neither the HER2-neu gene (4-6). These so called triple-negative breast cancers lack the benefits of specific therapies which target these receptors. Triple-negative breast cancers are relatively chemo-sensitive to conventional cytotoxic agents but tend to recur after short duration. Therefore, the development of new therapies is of importance.

The expression of luteinizing hormone releasing hormone (LHRH, GnRH) and its receptor as a part of a negative autocrine/paracrine regulatory mechanism of cell proliferation has been demonstrated in a number of malignant tumors, including cancers of the endometrium, ovary and breast (7). The LHRH receptor could be used for targeted chemotherapy to improve antitumor effects and reduce side effects compared with conventional systemic chemotherapy. LHRH agonists that are covalently linked to cytotoxic compounds bind specifically to LHRH receptors with their peptide moiety and act as chemotherapeutic agents after internalization of the ligand-receptor complex (8). Thus, these conjugates selectively affect those cells that express LHRH receptors and exert fewer side effects than unconjugated cytotoxic agents. LHRH agonists that have a D-Lys moiety at position 6 offer an amino side chain for a convenient attachment of various cytotoxic compounds. Even bulky molecules can be linked to the $\varepsilon$-amino group of the D-Lys ${ }^{6}$ moiety without a significant loss of binding affinity of the peptide portion to the receptors for LHRH (8). We were able to demonstrate that such a cytotoxic LHRH analogue, AEZS-108 (AN-152), in which doxorubicin is linked to the agonist carrier [D-Lys ${ }^{6}$ ] LHRH, is selectively internalized in human ovarian or endometrial cancer cell lines that express LHRH receptors. After internalization of AEZS-108 (AN-152), doxorubicin is cleaved 
from LHRH and accumulates in the nucleus. This uptake of AEZS-108 (AN-152) could be competitively inhibited by an excess of an LHRH agonist. In cancer cell lines that do not express LHRH receptors, no intracellular accumulation of AEZS-108 (AN-152) could be detected (9).

In the present study we have analyzed in vitro and in vivo whether cytotoxic LHRH agonist AEZS-108 (AN-152) is a suitable drug for an efficacious and less toxic therapy for triple-negative human breast cancers that express LHRH receptors.

\section{Materials and methods}

Cell lines and culture conditions. The triple-negative but LHRH receptor-positive human breast cancer cell lines HCC1806, HCC1937 and MDA-MB-231 were obtained from American Type Culture Collection (ATCC, Manassas, VA). In order to guarantee the identity of the cell lines over the years, the cells were expanded after purchase and aliquots were stored in liquid nitrogen. Every half year a new frozen stock was opened and expanded to carry out the experiments. The cells were cultured at $37^{\circ} \mathrm{C}$ in a humidified atmosphere of $5 \%$ $\mathrm{CO}_{2}$ in air as previously described (10-12).

Chemicals. The cytotoxic LHRH agonist AEZS-108 (AN-152), which consists of one molecule of doxorubicin-14-0-hemiglutarate linked covalently to the $\varepsilon$-amino group of the D-Lys ${ }^{6}$ moiety of [D-Lys ${ }^{6}$ LHRH, was a gift from Aeterna Zentaris GmbH (Frankfurt, Germany). Doxorubicin was purchased from Sigma Chemical Company (Deisenhofen, Germany).

Inhibition of serum carboxylesterase (CE). CE enzymes in fetal calf serum (FCS) can rapidly cleave AEZS-108 (AN-152), releasing the cytotoxic radical doxorubicin. The organophosphate diisopropyl fluorophosphate (DFP) was used to inhibit CE activity in FCS. At a maximum concentration of $0.25 \mathrm{~g} / \mathrm{ml}$, no toxic effect to the cells was observed. To inhibit $\mathrm{CE}$ in the culture medium containing $10 \%$ FCS cells were treated for $1 \mathrm{~h}$ with DFP before AEZS-108 (AN-152) or doxorubicin was added.

Human tissues. Specimens of human triple-negative breast cancers were obtained from paraffin sections of breast cancer (Department of Pathology, Georg-August-University, Göttingen, Germany). All tissues were obtained and processed in accordance with the ethics guidelines that were effective in the respective institutions at the time of collection and processing.

Animals. Female athymic (nude) mice (CD1 nu/nu), 6-8 weeks old on arrival, were obtained from Charles River (Sulzfeld, Germany). The mice were housed in sterile cages in a temperature-controlled room with 12-h light/12-h dark schedule and were fed autoclaved chow and water ad libitum. All experiments were done according to the German ethicsguidelines and the German laws for protection of animals.

Preparation of anti-human LHRH receptor antiserum. Two rabbits were immunized with $2 \mathrm{mg}$ of a synthetic peptide representing amino acids 1-29 (MANSASPEQ
NQNHCSAINNSIPLMQGNLPY) of the N-terminal of the human LHRH receptor extracellular region coupled to keyhole limpet haemocyanin via the Cys residue in complete Freund's adjuvant followed by three individual boosters at 3-week intervals in incomplete Freund's adjuvant. Blood was collected by heart puncture. Between the boosters and especially before the bleeding a small amount of blood was tested against ovalbumin-conjugated peptide to determine the titre of the corresponding serum (Peptide Specialty Laboratories GmbH, Heidelberg, Germany).

Immunohistochemistry. Paraffin sections of $4 \mu \mathrm{m}$ thickness of human triple-negative breast cancers were prepared and put on silane-coated slides. These slides were deparaffinized and rehydrated. Antigens were retrieved by incubation with $0.01 \mathrm{M}$ citrate buffer $(\mathrm{pH} 6.0)$ in a microwave $(700 \mathrm{~W})$ for $5 \mathrm{~min}$. Endogenous peroxidase activity was quenched by treatment with 3\% hydrogen peroxide solution for $6 \mathrm{~min}$. After washing in PBS, the slides were treated with polyclonal rabbit anti-human $\mathrm{LHRH}$ receptor antiserum in a 1:10,000 dilution in $1 \% \mathrm{BSA}$ in $10 \mathrm{~mm}$ Tris, $\mathrm{pH} 8.0,500 \mathrm{~mm} \mathrm{NaCl}$ and $0.1 \%$ Tween-20 (TBST) for $1 \mathrm{~h}$ and, after being washed, were detected with the ready-to-use secondary antibody horseradish peroxidase-conjugated anti-rabbit $\mathrm{IgG}$ detection system according to the instructions of the supplier (Zymed Laboratories, San Francisco, CA, USA). Controls were perfomed by substitution of the primary antiserum with pre-immune serum of the same rabbit. Counterstaining was performed using Mayer's haematoxylin for $10 \mathrm{sec}$. The slides were then dehydrated, cleared, mounted with Permount and studied by light microscopy.

Proliferation assay. Five hundred cells per well were plated into 96-well plates (Falcon, Heidelberg) in $100 \mu 1 \mathrm{DMEM} / 5 \%$ fetal calf serum (FCS, Biochrom, Berlin) without phenol red, $2 \mathrm{mM}$ glutamine, $50 \mathrm{U} / \mathrm{ml}$ penicillin/streptomycin, $2.5 \mu \mathrm{g} / \mathrm{ml}$ amphotericin B, and 1:100 non-essential amino acids. After cell attachment, $100 \mu \mathrm{l}$ medium or $100 \mu \mathrm{l}$ AEZS-108 (AN-152) solution at increasing final concentrations of $10^{-11}-10^{-5} \mathrm{M}$ was added to the wells in six replicates and incubated for 5 days at $37^{\circ} \mathrm{C}, 5 \% \mathrm{CO}_{2}$. Cell number was determined by a colorimetric assay using Alamar Blue (Biosource, Solingen, Germany). The optical density (OD) of the reduced dye is assessed at $570 \mathrm{~nm}$ vs. $630 \mathrm{~nm}$ after $4 \mathrm{~h}$ at $37^{\circ} \mathrm{C}$.

Mitochondrial membrane potential. For determination of AEZS-108 (AN-152)-induced loss of mitochondrial membrane potential, cells were treated without or with the AEZS-108 (AN-152; $10^{-9}$ and $10^{-7} \mathrm{M}$ ) for $72 \mathrm{~h}$. After incubation the cells were washed with PBS once and the mitochondrial membrane potential was detected using the JC-1 mitochondrial membrane potential detection kit according the instructions of the manufacturer (Biotium, Hayward, CA).

Western blot analysis of caspase-3 activity. For determination of AEZS-108 (AN-152)-induced caspase-3 activity, the cells were treated without or with AEZS-108 (AN-152; 2x10-6 and $5 \times 10^{-6} \mathrm{M}$ ) for 24 and $48 \mathrm{~h}$. After incubation the cells were detached immediately with $0.5 \mathrm{~g}$ trypsin (Biochrom, Berlin, Germany) and 5 mmol EDTA in 1 lt PBS/BSA. The 
pellets were washed twice with PBS and resuspended with CelLytic $^{\text {TM }}$ buffer (Sigma) containing protease inhibitors (Sigma). Equal amounts of protein per sample were used and diluted to equal volumes with Laemmli buffer. The cell lysates were separated on SDS-PAGE $\left(15 \%\right.$, ProSieve ${ }^{\circledR} 50$ Gel Solution, Cambrex, Verviers, Belgium) under reducing conditions and transferred to nitrocellulose membranes (Hybond-ECL, GE Healthcare Europe, Munich, Germany). The nitrocellulose membranes were blocked with $5 \%$ instant skimmed milk powder, spray-dried (Naturaflor, Töpfer $\mathrm{GmbH}$, Dietmannsried, Germany) in TBST (137 mM NaCl, $2.7 \mathrm{mM} \mathrm{KCl}, 0.1 \%$ Tween-20, $25 \mathrm{mM}$ Tris/Cl, $\mathrm{pH}$ 7.4) for $1 \mathrm{~h}$ at RT, washed with TBST and then incubated at $4^{\circ} \mathrm{C}$ overnight with rabbit anti-human active caspase- 3 polyclonal antibody (BD PharMingen, Heidelberg, Germany) in a 1:5,000 dilution in TBST and then, following washings, incubated at RT with horseradish peroxidase-conjugated anti-rabbit IgG (GE Healthcare Europe) at an 1:10,000 dilution in TBST for $1 \mathrm{~h}$. After washings, specifically bound antibody was detected using the enhanced chemiluminescence kit (ECL; Millipore, Schwalbach, Germany). The bands were analyzed using the Kodak 1D image system (Kodak, New Haven, CT, USA).

In vivo studies. Tumors were initiated by subcutaneous injection of $1 \times 10^{7}$ cancer cells into the right flank. After 2 (HCC 1806) or 3 (MDA-MB-231) weeks all animals had developed solid tumors of about $80 \mathrm{~mm}^{3}$ and treatment was initiated. The in vivo experiments were done as follows: vehicle solution (control), $60 \mathrm{nmol}$ of doxorubicin or $60 \mathrm{nmol}$ of AEZS-108 (AN-152) per mouse (5 mice per group) were injected intraperitoneally. Treatment was repeated every 3 days (days $0,3,6,9$ and 12). Tumor volumes were measured on days $0,3,6,9,12$ and 15 of treatment. The mice were sacrificed after 15 days.

Statistical analysis. All experiments were repeated three times with different passages of the respective cell lines. The data were tested for significant differences by one-way analysis of variance followed by Student-Newman-Keuls' test for comparison of individual groups, after a Bartlett test had shown that variances were homogeneous.

\section{Results}

LHRH receptor expression. Forty-two triple-negative human breast cancer specimens were analyzed for LHRH receptor expression. Eleven (26.2\%) triple-negative human breast cancer specimens were LHRH receptor-negative. Thirty-one (73.8\%) triple-negative human breast cancer specimens showed LHRH receptor expression. Twenty-two of these 31 LHRH receptor-positive specimens (71.0\%) showed LHRH receptor antigenicity in $100 \%$ of the tumor cells. Six of the 31 LHRH receptor-positive specimens (19.3\%) showed LHRH receptor antigenicity in approximately $80 \%$ of the tumor cells. Three of the $31 \mathrm{LHRH}$ receptor-positive specimens $(9.7 \%)$ showed LHRH receptor antigenicity in approximately 10, 25, and $40 \%$ of the tumor cells.

Effects of AEZS-108 (AN-152) on cell proliferation. Cell number was quantified using Alamar Blue colorimetric assay. Treatment of HCC1806 and HCC1937 human breast cancer
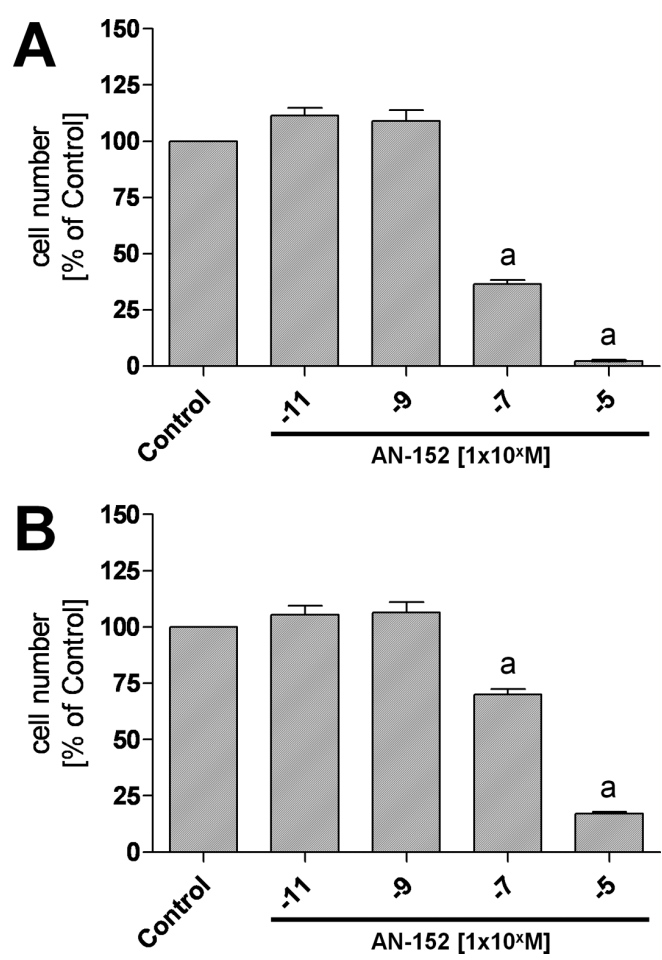

Figure 1. Dose-response experiments on cell proliferation of human triplenegative but LHRH receptor-positive HCC1806 (A) and HCC1937 (B) human breast cancer cells in vitro. Cells were incubated for 5 days without (control) or with increasing AEZS-108 (AN-152) concentrations. Cell number is given as a percentage of controls $(100 \%)$. Columns represent means \pm SEM of data obtained from three independent experiments in three different passages of the respective cell line. a, $\mathrm{P}<0.001$ vs. control. Experiments using MDAMB-231 human breast cancer cells gave comparable results.

cells with increasing concentrations $\left(10^{-11} \mathrm{M}-10^{-5} \mathrm{M}\right)$ of AEZS-108 (AN-152) for 5 days resulted in a reduction of cell number (Fig. 1)

After treatment of HCC1806 breast cancer cells (Fig. 1A) with $10^{-11} \mathrm{M}$ and $10^{-9} \mathrm{M}$ of AEZS-108 (AN-152) no reduction of cell number was detectable. Treatment with $10^{-7} \mathrm{M}$ of AEZS-108 (AN-152) resulted in a decrease of cell number to $36.48 \pm 1.83 \%$ of control $(=100 \%$; $\mathrm{P}<0.001)$. The effects were maximal at $10^{-5} \mathrm{M}$ concentrations of AEZS-108 (AN-152) and corresponded to a decrease of cell number to $2.32 \pm 0.24 \%$ of control $(=100 \% ; \mathrm{P}<0.001)$.

After treatment of HCC1937 breast cancer cells (Fig. 1B) with $10^{-11} \mathrm{M}$ and $10^{-9} \mathrm{M}$ of AEZS-108 (AN-152) no reduction of cell number was detectable. Treatment with $10^{-7} \mathrm{M}$ of AEZS-108 (AN-152) resulted in a decrease of cell number to $70.02 \pm 2.46 \%$ of control $(=100 \% ; \mathrm{P}<0.001)$. The effects were maximal at $10^{-5} \mathrm{M}$ concentrations of AEZS-108 (AN-152) and corresponded to a decrease of cell number to $17.15 \pm 0.62 \%$ of control $(=100 \% ; \mathrm{P}<0.001)$. Experiments using the breast cancer cell line MDA-MB-231 gave comparable results (data not shown).

Effects of AEZS-108 (AN-152) on mitochondrial membrane potential. Induction of apoptosis was analyzed by measurement of the loss of the mitochondrial membrane potential $(\Delta \Psi)$. Treatment of HCC1806 and HCC1937 human breast cancer cells with increasing concentrations $\left(10^{-9} \mathrm{M}\right.$ and 

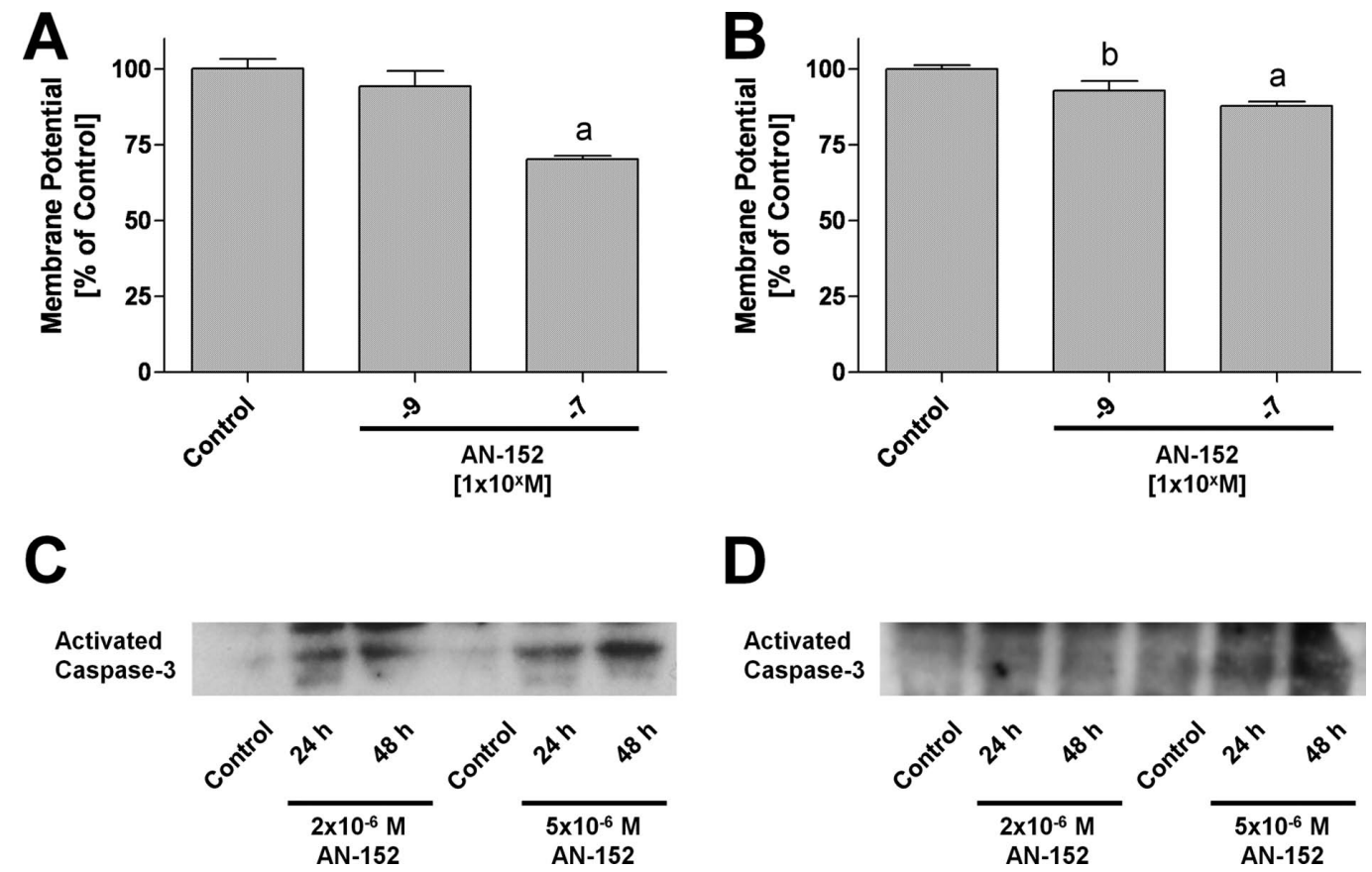

Figure 2. Effects of AEZS-108 (AN-152) treatment on induction of apoptosis in triple-negative but LHRH receptor-positive HCC1806 (A and C) and HCC1937 (B and D) human breast cancer cells in vitro. (A and B) Percentage of mitochondrial membrane potential $(\Delta \Psi)$ after $72 \mathrm{~h}$ of treatment of HCC1806 (A) and HCC1937 (B) breast cancer cells without (control $=100 \%$ ) or with AEZS-108 (AN-152; $10^{-9} \mathrm{M}$ and $10^{-7} \mathrm{M}$ ). Columns represent means \pm SEM of data obtained from three independent experiments in three different passages of the respective cell line. a, $\mathrm{P}<0.001$ vs. control; b, P $<0.05$ vs. control. Experiments using MDA-MB-231 human breast cancer cells gave comparable results. (C and D) Activation of caspase-3 after 24 and $48 \mathrm{~h}$ of treatment of HCC1806 (C)

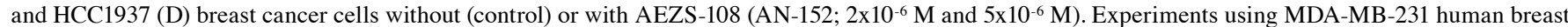
cancer cells gave comparable results.

$\left.10^{-7} \mathrm{M}\right)$ of AEZS-108 (AN-152) for $72 \mathrm{~h}$ resulted in a reduction of mitochondrial membrane potential (Fig. 2A and B).

Treatment of HCC1806 breast cancer cells (Fig. 2A) with $10^{-9} \mathrm{M}$ of AEZS-108 (AN-152) resulted in a slight decrease of mitochondrial membrane potential to $94.26 \pm 5.18 \%$ of control (= $100 \%$; not significant). At $10^{-7} \mathrm{M}$ concentrations of AEZS-108 (AN-152) the decrease of mitochondrial membrane potential was significant and corresponded to a decrease of mitochondrial membrane potential to $70.24 \pm 1.08 \%$ of control (= $100 \% ; \mathrm{P}<0.001)$.

After treatment of HCC1937 breast cancer cells (Fig. 2B) with $10^{-9} \mathrm{M}$ of AEZS-108 (AN-152) resulted in a slight decrease of mitochondrial membrane potential to $92.92 \pm 3.19 \%$ of control $(=100 \% ; \mathrm{P}<0.05)$. At $10^{-7} \mathrm{M}$ concentrations of AEZS-108 (AN-152) the decrease of mitochondrial membrane potential was significant and corresponded to a decrease of mitochondrial membrane potential to $87.75 \pm 1.49 \%$ of control $(=100 \% ; \mathrm{P}<0.001)$. Experiments using the breast cancer cell line MDA-MB-231 gave comparable results (data not shown).

Effects of AEZS-108 (AN-152) on caspase-3 activity. The effects of AN-153 on induction of apoptotic cell death could be confirmed by measurement of caspase-3 activity (Fig. 2C and D).

Treatment of HCC1806 (Fig. 2C) and HCC1937 (Fig. 2D) breast cancer cells with $2 \times 10^{-6} \mathrm{M}$ of AEZS-108 (AN-152) resulted in a clear increase of caspase-3 activation. At $2 \times 10^{-6} \mathrm{M}$ concentrations of AEZS-108 (AN-152) the increase of caspase- 3 activation was still clearer.
Effects of AEZS-108 (AN-152) on tumor growth in vivo. To show the proof-of-principle of an anti-tumor therapy using AEZS-108 (AN-152), nude mice bearing xenografted triple-negative human breast tumors s.c. were treated with AEZS-108 (AN-152) (Fig. 3).

Experiment 1. In experiment 1 (Fig. 3A) female CD1 nu/nu mice bearing triple-negative $\mathrm{HCC} 1806$ human breast tumors s.c. were treated without (control I) or with $60 \mathrm{nmol} / 20 \mathrm{~g}$ per injection of doxorubicin (control II) or with $60 \mathrm{nmol} / 20 \mathrm{~g}$ per injection of AEZS-108 (AN-152). The treatments were repeated every 3 days (5 injections total), and tumor volumes were measured every 3 days. The mice were sacrificed after 15 days of treatment. Side effects were not observed.

After 3 days of treatment, the volume of the HCC1806 cancers in the group that received AEZS-108 (AN-152) was slightly increased to $105.7 \pm 4.8 \%$ of the initial volume $(=100 \%$; $\mathrm{P}<0.001$ vs. control group on day 3 ). The tumor volume of the control animals enlarged to $165.9 \pm 6.0 \%$ of the initial volume $(=100 \%)$. In the doxorubicin treated group, the volume of the HCC1806 cancers increased to $114.1 \pm 4.3 \%$ of the initial volume $(=100 \% ; \mathrm{P}<0.001$ vs. control group on day 3$)$.

After 6 days of treatment, the volume of the HCC1806 cancers in the group that received AEZS-108 (AN-152) was slightly reduced to $97.7 \pm 8.0 \%$ of the initial volume $(=100 \%$; $\mathrm{P}<0.001$ vs. control group on day $6 ; \mathrm{P}<0.01$ vs. doxorubicin group on day 6), which represented less than one third of the tumor volume of the control animals that enlarged to $316.1 \pm 19.5 \%$ of the initial volume $(=100 \%)$. In the doxorubicin treated group, the volume of the HCC1806 cancers increased 

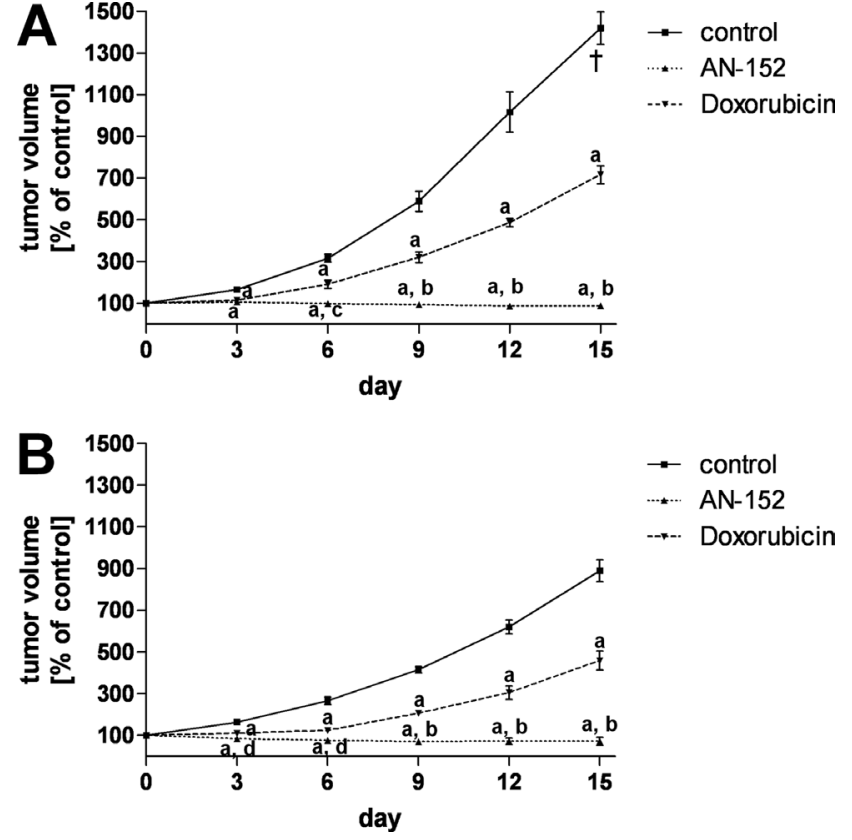

Figure 3. Tumor volume of triple-negative HCC1806 (A) and MDA-MB-23 (B) human breast cancers xenografted into nude mice. The mice were treated without (vehicle solution, control), with $60 \mathrm{nmol}$ of doxorubicin or with $60 \mathrm{nmol}$ of cytotoxic LHRH agonist AEZS-108 (AN-152). Treatment was repeated every 3 days (days $0,3,6,9$ and 12). Tumor volumes were measured on days $0,3,6,9,12,15$ of treatment. The mice were sacrificed after 15 days. All experimental groups consisted of 5 animals. Vertical bars represent SEM. a, $\mathrm{P}<0.001$ vs. control; $\mathrm{b}, \mathrm{P}<0.001$ vs. doxorubicin treated group; c, $\mathrm{P}<0.01$ vs. doxorubicin treated group; $\mathrm{d}, \mathrm{P}<0.05$ vs. doxorubicin treated group.

to $190.9 \pm 20.2 \%$ of the initial volume $(=100 \%$; $\mathrm{P}<0.001$ vs control group on day 6), but this was approximately two third of the tumor volume of the control animals.

After 9 and 12 days of treatment, the volume of the HCC1806 cancers in the group that received AEZS-108 (AN-152) was further reduced to $93.5 \pm 7.3 \%$ (day 9; $\mathrm{P}<0.001$ vs. control group on day $9 ; \mathrm{P}<0.001$ vs. doxorubicin group on day 9) and to $86.9 \pm 5.6 \%$ (day $12 ; \mathrm{P}<0.001$ vs. control group on day $12 ; \mathrm{P}<0.001$ vs. doxorubicin group on day 12 ) of the initial volume $(=100 \%)$ respectively. In the control group, the tumor volume increased to $588.9 \pm 47.9 \%$ of the initial volume $(=100 \%)$ on day 9 and to $1017 \pm 96.8 \%$ of the initial volume $(=100 \%)$ on day 12 . After 9 and 12 days of treatment, the tumor volume of the doxorubicin treated group increased to $320.6 \pm 25.7 \%$ (day 9; $\mathrm{P}<0.001$ vs. control group on day 9) and to $486.7 \pm 20.2 \%$ (day $12 ; \mathrm{P}<0.001$ vs. control group on day 12 ) of the initial volume $(=100 \%)$.

After 15 days of treatment, the volume of the HCC1806 cancers in the group that received AEZS-108 (AN-152) was $88.0 \pm 9.7 \%$ of the initial volume $(=100 \%$; $<<0.001$ vs. control group on day $15 ; \mathrm{P}<0.001$ vs. doxorubicin group on day 15 ), which represented approximately $6 \%$ of the tumor volume of the control animals that enlarged to $1420 \pm 77.6 \%$ of the initial volume $(=100 \%)$. After 15 days of treatment, the tumor volume of the doxorubicin treated group increased to $716.0 \pm 43.1 \%$ of the initial volume $(=100 \% ; \mathrm{P}<0.001$ vs. control group on day 15), which represented more than $800 \%$ of the tumor volume of the AEZS-108 (AN-152) treated animals on day 15, but this was approximately one half of the tumor volume of the control animals on day 15 .

Experiment 2. Since HCC1937 breast cancer cells do not form tumors in nude mice we used MDA-MB-231 breast cancer cells (Fig. 3B) to perform a second experiment. Female CD1 $\mathrm{nu} / \mathrm{nu}$ mice bearing triple-negative MDA-MB-231 human breast tumors s.c. were treated without (control I) or with $60 \mathrm{nmol} / 20 \mathrm{~g}$ per injection of doxorubicin (control II) or with $60 \mathrm{nmol} / 20 \mathrm{~g}$ per injection of AEZS-108 (AN-152). The treatments were repeated every 3 days (5 injections total), and tumor volumes were measured every 3 days. The mice were sacrificed after 15 days of treatment. Side effects were not observed.

After 3 days of treatment, the volume of the MDA-MB-231 cancers in the group that received AEZS-108 (AN-152) was decreased to $84.8 \pm 7.6 \%$ of the initial volume $(=100 \% ; \mathrm{P}<0.001$ vs. control group on day $3 ; \mathrm{P}<0.05$ vs. doxorubicin group on day 3), which represented approximately one half of the tumor volume of the control animals that enlarged to $164.1 \pm 10.5 \%$ of the initial volume $(=100 \%)$. In the doxorubicin treated group, the volume of the MDA-MB-231 cancers increased to $110.2 \pm 5.4 \%$ of the initial volume $(=100 \% ; \mathrm{P}<0.001$ vs. control group on day 3 ).

After 6, 9, and 12 days of treatment, the volume of the MDA-MB-231 cancers in the group that received AEZS-108 (AN-152) was further reduced to $75.3 \pm 10.6 \%$ (day 6; $\mathrm{P}<0.001$ vs. control group on day $6 ; \mathrm{P}<0.05$ vs. doxorubicin group on day 6), $70.0 \pm 11.7 \%$ (day 9; $\mathrm{P}<0.001$ vs. control group on day 9; $\mathrm{P}<0.001$ vs. doxorubicin group on day 9), and $72.6 \pm 16.0 \%$ (day $12 ; \mathrm{P}<0.001$ vs. control group on day $12 ; \mathrm{P}<0.001$ vs. doxorubicin group on day 12$)$ of the initial volume $(=100 \%)$ respectively. In the control group, the tumor volume increased to $267.2 \pm 18.2 \%$ of the initial volume $(=100 \%)$ on day 6 , $415.8 \pm 15.1 \%$ of the initial volume $(=100 \%)$ on day 9 , and $620.8 \pm 33.3 \%$ of the initial volume $(=100 \%)$ on day 12 . After 6, 9, and 12 days of treatment, the tumor volume of the doxorubicin treated group increased to $124.8 \pm 6.1 \%$ (day 6; $\mathrm{P}<0.001$ vs. control group on day 6), 206.7 $\pm 11.8 \%$ (day 9; $\mathrm{P}<0.001$ vs. control group on day 9), and $305.4 \pm 33.2 \%$ (day $12 ; \mathrm{P}<0.001$ vs. control group on day 12 ) of the initial volume $(=100 \%)$.

After 15 days of treatment, the volume of the MDA-MB-231 cancers in the group that received AEZS-108 (AN-152) was $72.4 \pm 18.7 \%$ of the initial volume $(=100 \%$; $\mathrm{P}<0.001$ vs. control group on day $15 ; \mathrm{P}<0.001$ vs. doxorubicin group on day 15$)$, which represented approximately $8 \%$ of the tumor volume of the control animals that enlarged to $890.0 \pm 53.4 \%$ of the initial volume $(=100 \%)$. After 15 days of treatment, the tumor volume of the doxorubicin treated group increased to $459.6 \pm 45.7 \%$ of the initial volume $(=100 \% ; \mathrm{P}<0.001$ vs. control group on day $15)$, which represented more than $600 \%$ of the tumor volume of the AEZS-108 (AN-152) treated animals on day 15, but this was approximately one half of the tumor volume of the control animals on day 15 .

\section{Discussion}

Previous study showed that AEZS-108 (AN-152) induces apoptotic cell death in LHRH receptor-positive human endo- 
metrial, ovarian and breast cancer cells in vitro and in vivo $(9,13,14)$. In addition, we could demonstrate that AEZS-108 (AN-152)-induced apoptosis in human endometrial, ovarian and breast cancer cell lines is independent of the multidrug resistance-1 (MDR-1) system $(15,16)$. Because of the LHRH receptor-mediated entry of AEZS-108 (AN-152) into the cancer cells, AEZS-108 (AN-152) may overcome chemoresistance, which is a major drawback of systemic therapy of these malignancies by anthracyclines $(15,16)$.

Receptors for LHRH have been reported in 52-64\% of human breast cancers (17-19). Here we could show that 31 of 42 triple-negative breast cancers $(73.8 \%)$ were LHRH receptor-positive. In addition, apart from reproductive organs, other organs and hematopoietic stem cells do not express LHRH receptors (14). Only in the human ovary, endometrium, myometrium, fallopian tube and the cervix, i.e. tissues derived from the müllerian epithelium, that expression of LHRH receptors was detected (14). Thus, cytotoxic LHRH agonists such as AEZS-108 (AN-152) appear to be suitable drugs for a more efficacious and less toxic targeted chemotherapy for triple-negative breast cancers.

Triple-negative breast cancer refers to a specific subtype of breast cancer that is characterized by lack of expression of both, estrogen and progesterone receptors as well as HER2-neu protein. Clinically triple-negative breast cancer is more aggressive and associated with poorer overall patient prognosis $(20,21)$. To date, the therapeutic options are very limited leaving chemotherapy the only possible therapy. Treatment with the cytotoxic LHRH agonist AEZS-108 (AN-152) could be a new option for the therapy of triplenegative breast cancer as approximately $74 \%$ of these tumors $(n=42)$ might express LHRH receptors. In a recent study Buchholz et al found LHRH receptor expression in all analyzed human triple-negative breast cancers $(n=16)(22)$.

In the present study we could demonstrate that treatment of triple-negative HCC1806, HCC1937, and MDA-MB-231 human breast cancer cells with cytotoxic LHRH agonist AEZS-108 (AN-152) in vitro resulted in apoptotic cell death via loss of mitochondrial membrane potential and activation of caspase-3. In addition we showed the proof-of-principle of an antitumor therapy using AEZS-108 (AN-152) in vivo in nude mice bearing s.c. xenografts of human triple-negative breast cancers. Nude mice bearing HCC1806 or MDA-MB231 triple-negative human breast cancers were treated without or with AEZS-108 (AN-152) or with doxorubicin. The tumor growth of the mice receiving therapy with AEZS-108 (AN-152) was not only significantly reduced, but even arrested. In addition we demonstrated that AEZS-108 (AN-152) is more effective than doxorubicin in inducing apoptosis in triple-negative, but LHRH receptor-positive human breast tumors in vivo. The increase of the tumor volume of the mice receiving therapy with doxorubicin was significantly lower than with the control animals but significantly higher than with the AEZS-108 (AN-152) treated group. Toxic side effects were not observed. Our findings could be the basis for a further evaluation in clinical trials. In a current phase II study AEZS-108 (AN-152) was found to be active and well tolerated in patients with heavily pretreated platinum- and taxane-resistant LHRH receptor-positive ovarian cancer (23).
Non-toxic LHRH agonists and LHRH antagonists have been widely used in the therapy of cancer (24-28) and endometriosis (29-31) as well as in reproductive medicine (32-36). Their effects are mainly due to the down-regulation of the hypothalamic-ovarian axis and the resulting medical castration, but triple-negative breast cancer cells are insensitive to estrogen deprivation.

In conclusion, we could show that about three quarters of triple-negative human breast cancers express LHRH receptors and that AEZS-108 (AN-152) induces apoptotic cell death in triple-negative HCC1806, HCC1937, and MDA-MB-231 human breast cancer cells in vitro and in vivo. Apoptosis induced by AEZS-108 (AN-152) is mediated through the intrinsic apoptotic pathway via loss of mitochondrial membrane potential and activation of caspase-3.

Thus, cytotoxic LHRH agonist AEZS-108 (AN-152) seems to be a suitable drug for an efficacious and less toxic targeted chemotherapy for triple-negative, but LHRH receptor-positive breast cancers.

\section{Acknowledgements}

This study was supported by a grant of the Deutsche Krebshilfe, Dr Mildred Scheel Stiftung. We thank Aeterna Zentaris GmbH (Frankfurt, Germany) for the gift of the cytotoxic LHRH agonist AEZS-108 (AN-152). We thank Sonja Blume, Renate Dietrich, Matthias Läsche and Hildtrud Schulz for excellent technical assistance.

\section{References}

1. Ferlay J, Bray F, Pisani P and Parkin DM: GLOBOCAN 2000: cancer incidence, mortality and prevalence worldwide, version 1.0. IARC CancerBase No. 5. IARC Press, Lyon, 2001.

2. Dawson SJ, Provenzano E and Caldas C: Triple negative breast cancers: clinical and prognostic implications. Eur J Cancer 45 (Suppl. 1): 27-40, 2009.

3. Konecny G, Pauletti G, Pegram M, et al: Quantitative association between HER-2/neu and steroid hormone receptors in hormone receptor-positive primary breast cancer. J Natl Cancer Inst 95: 142-153, 2003.

4. Kim MJ, Ro JY, Ahn SH, Kim HH, Kim SB and Gong G: Clinicopathologic significance of the basal-like subtype of breast cancer: a comparison with hormone receptor and Her2/ neu-overexpressing phenotypes. Hum Pathol 37: 1217-1226, 2006.

5. Nielsen TO, Hsu FD, Jensen K, et al: Immunohistochemical and clinical characterization of the basal-like subtype of invasive breast carcinoma. Clin Cancer Res 10: 5367-5374, 2004.

6. Bauer KR, Brown M, Cress RD, Parise CA and Caggiano V: Descriptive analysis of estrogen receptor (ER)-negative, progesterone receptor (PR)-negative, and HER2-negative invasive breast cancer, the so-called triple-negative phenotype: a population-based study from the California Cancer Registry. Cancer 109: 1721-1728, 2007.

7. Grundker C, Gunthert AR, Westphalen S and Emons G: Biology of the gonadotropin-releasing hormone system in gynecological cancers. Eur J Endocrinol 146: 1-14, 2002.

8. Schally AV and Nagy A: Cancer chemotherapy based on targeting of cytotoxic peptide conjugates to their receptors on tumors. Eur J Endocrinol 141: 1-14, 1999.

9. Westphalen S, Kotulla G, Kaiser F, et al: Receptor mediated antiproliferative effects of the cytotoxic LHRH agonist AN-152 in human ovarian and endometrial cancer cell lines. Int J Oncol 17: 1063-1069, 2000.

10. Emons G, Ortmann O, Becker M, et al: High affinity binding and direct antiproliferative effects of LHRH analogues in human ovarian cancer cell lines. Cancer Res 53: 5439-5446, 1993. 
11. Emons G, Schroder B, Ortmann O, Westphalen S, Schulz KD and Schally AV: High affinity binding and direct antiproliferative effects of luteinizing hormone-releasing hormone analogs in human endometrial cancer cell lines. J Clin Endocrinol Metab 77: 1458-1464, 1993.

12. Irmer G, Burger C, Muller R, et al: Expression of the messenger RNAs for luteinizing hormone-releasing hormone (LHRH) and its receptor in human ovarian epithelial carcinoma. Cancer Res 55: 817-822, 1995.

13. Grundker C: Cytotoxic luteinizing hormone-releasing hormone conjugates and their use in gynecological cancer therapy. Eur J Endocrinol 143: 569-572, 2000.

14. Grundker C, Volker P, Griesinger F, et al: Antitumor effects of the cytotoxic luteinizing hormone-releasing hormone analog AN-152 on human endometrial and ovarian cancers xenografted into nude mice. Am J Obstet Gynecol 187: 528-537, 2002.

15. Gunthert AR, Grundker C, Bongertz T, Nagy A, Schally AV and Emons G: Induction of apoptosis by AN-152, a cytotoxic analog of luteinizing hormone-releasing hormone (LHRH), in LHRH-R positive human breast cancer cells is independent of multidrug resistance-1 (MDR-1) system. Breast Cancer Res Treat 87: 255-264, 2004

16. Gunthert AR, Grundker C, Bongertz T, et al: Internalization of cytotoxic analog $\mathrm{AN}-152$ of luteinizing hormone-releasing hormone induces apoptosis in human endometrial and ovarian cancer cell lines independent of multidrug resistance-1 (MDR-1) system. Am J Obstet Gynecol 191: 1164-1172, 2004.

17. Fekete M, Wittliff JL and Schally AV: Characteristics and distribution of receptors for [D-TRP6]-luteinizing hormonereleasing hormone, somatostatin, epidermal growth factor, and sex steroids in 500 biopsy samples of human breast cancer. J Clin Lab Anal 3: 137-147, 1989.

18. Baumann KH, Kiesel L, Kaufmann M, Bastert G and Runnebaum B: Characterization of binding sites for a $\mathrm{GnRH}$ agonist (buserelin) in human breast cancer biopsies and their distribution in relation to tumor parameters. Breast Cancer Res Treat 25: 37-46, 1993

19. Moriya T, Suzuki T, Pilichowska M, et al: Immunohistochemical expression of gonadotropin releasing hormone receptor in human breast carcinoma. Pathol Int 51: 333-337, 2001

20. Dent R, Trudeau M, Pritchard KI, et al: Triple-negative breast cancer: clinical features and patterns of recurrence. Clin Cancer Res 13: 4429-4434, 2007

21. Gluz O, Liedtke C, Gottschalk N, Pusztai L, Nitz U and Harbeck N: Triple-negative breast cancer-current status and future directions. Ann Oncol 20: 1913-1927, 2009.

22. Buchholz S, Seitz S, Schally AV, et al: Triple-negative breast cancers express receptors for luteinizing hormone-releasing hormone (LHRH) and respond to LHRH antagonist cetrorelix with growth inhibition. Int J Oncol 35: 789-796, 2009.
23. Emons G, Tomov S, Harter P, et al: Phase II study of AEZS-108 (AN-152), a targeted cytotoxic LHRH analog, in patients with LHRH receptor-positive platinum resistant ovarian cancer. J Clin Oncol 28 (Suppl): abs. 5035, 2010.

24. Emons G, Grundker C, Gunthert AR, Westphalen S, Kavanagh J and Verschraegen C: GnRH antagonists in the treatment of gynecological and breast cancers. Endocr Relat Cancer 10: 291-299, 2003.

25. Labrie F, Belanger A, Luu-The V, et al: Gonadotropin-releasing hormone agonists in the treatment of prostate cancer. Endocr Rev 26: 361-379, 2005.

26. Robertson JF and Blamey RW: The use of gonadotrophinreleasing hormone $(\mathrm{GnRH})$ agonists in early and advanced breast cancer in pre- and perimenopausal women. Eur J Cancer 39: $861-869,2003$.

27. Sharma R, Beith J and Hamilton A: Systematic review of LHRH agonists for the adjuvant treatment of early breast cancer. Breast 14: 181-191, 2005.

28. Weckermann D and Harzmann R: Hormone therapy in prostate cancer: LHRH antagonists versus LHRH analogues. Eur Urol 46: 274-283, 2004.

29. Barbieri RL: Gonadotropin-releasing hormone agonists: treatment of endometriosis. Clin Obstet Gynecol 36: 636-641, 1993.

30. Barbieri RL: Primary gonadotropin-releasing hormone agonist therapy for suspected endometriosis: a non-surgical approach to the diagnosis and treatment of chronic pelvic pain. Am J Manag Care 3: 285-290, 1997.

31. Olive DL: Optimizing gonadotropin-releasing hormone agonist therapy in women with endometriosis. Treat Endocrinol 3: 83-89, 2004.

32. Al-Inany $\mathrm{H}$ and Aboulghar $\mathrm{M}$ : GnRH antagonist in assisted reproduction: a Cochrane review. Hum Reprod 17: 874-885, 2002.

33. Cardone VS: GnRH antagonists for treatment of polycystic ovarian syndrome. Fertil Steril 80 (Suppl. 10): S24-S32, 2003.

34. Griesinger G, Diedrich K, Devroey P and Kolibianakis EM $\mathrm{GnRH}$ agonist for triggering final oocyte maturation in the GnRH antagonist ovarian hyperstimulation protocol: a systematic review and meta-analysis. Hum Reprod Update 12: 159-168, 2006.

35. Olivennes F, Cunha-Filho JS, Fanchin R, Bouchard P and Frydman R: The use of GnRH antagonists in ovarian stimulation. Hum Reprod Update 8: 279-290, 2002.

36. Tarlatzis BC, Fauser BC, Kolibianakis EM, Diedrich K, Rombauts L and Devroey P: GnRH antagonists in ovarian stimulation for IVF. Hum Reprod Update 12: 333-340, 2006. 